\title{
Strategies for media literacy: Audiovisual skills and the citizenship in Andalusia
}

\author{
Ignacio Aguaded-Gómez ${ }^{1,}$,, M. Amor Pérez-Rodríguez² \\ 1Departamento de Educación, Universidad de Huelva, Spain \{aguaded@uhu.es\} \\ 2Departamento de Filología Española y sus Didácticas, Universidad de Huelva, Spain \{amor@uhu.es\} \\ Received on 21 March 2012; revised on 10 May 2012; accepted on 10 May 2012; published on 15 July 2015
}

DOI: 10.7821/naer.1.1.22-26

\begin{abstract}
Media consumption is an undeniable fact in present-day society. The hours that members of all social segments spend in front of a screen take up a large part of their leisure time worldwide. Audiovisual communication becomes especially important within the context of today's digital society (society-network), where information and communication technologies pervade all corners of everyday life. However, people do not own enough audiovisual media skills to cope with this mass media omnipresence. Neither the education system nor civic associations, or the media themselves, have promoted audiovisual skills to make people critically competent when viewing media. This study aims to provide an updated conceptualization of the "audiovisual skill" in this digital environment and transpose it onto a specific interventional environment, seeking to detect needs and shortcomings, plan global strategies to be adopted by governments and devise training programmes for the various sectors involved
\end{abstract}

KEYWORDS: MEDIA LITERACY, SKILLS, AUDIOVISUAL COMMUNICATION, MEDIA EDUCATION, CITIZENSHIP, COMPULSORY EDUCATION, DIGITAL ENVIRONMENT, TRAINING PROGRAMMES, FREE TIME

\section{INTRODUCTION}

The research Project presented in this paper aims to introduce the concept of "audiovisual skills" in Andalusian citizenship by means of the analysis of the main shortages and needs of citizens, as well as establishing a wide assessment programme to obtain training initiatives and conclusions.

Over the last decades, the concept of skill in terms of audiovisual communication has increasingly acquired a scientific dimension due to the widespread influence of the media in our current society, especially boosted by the development of Information and Communication Technologies. The Italian writer Umberto Eco already stated in 1977 that: "democratic civilization would only success if we transform language into a provocation for critical thought instead of presenting language as an invitation to hypnosis". After thirty years, the command of abilities to code and decode audiovisual messages has become a basic step in literacy terms, in the same way that reading and writing skills were basic steps in our traditional culture.

In this sense, language of moving or still images should become a basic skill for citizens in order to avoid possible manipulations. Technological advance has achieved unexpected limits in terms of images diffusion and also in terms of audience's interests. However, efforts to develop training for critical thought have not been developed at the same rhythm.

In global terms, the concept of audiovisual skill has not been widely explored yet. There are scarce studies analyzing the grade of knowledge and comprehension of audiovisual media elements, especially among most vulnerable groups of society such as children and teenagers. In parallel with the wave of transformations we are witnessing, communication tools for children and teenagers are nowadays even more complex and appear in different formats being continuously updated. That is why, in order to create leisure programmes to encourage reading comprehension and realization of media, it would be necessary to determine the real level of skill, scientifically analyzing the context and the matter. As it was stated by Prensky in 2001, after introducing the term "digital native", "young people interact with the media with a low training level or simply lacking from required knowledge of audiovisual power". This affirmation has been recently ratified by him on his report "How teens use media. A Nielsen Report on the myths and realities of teen media trends" (2009). Undoubtedly, citizenship is witnessing the evolution towards the digitalism but without the knowledge required to do so.

The main purpose of this study would be to evidence the urgency to assess skills on audiovisual communication, as they are not frequently taught in a systematic way and consequently, not assessed to determine the main shortages and needs. On the other side, efficient assessment systems are unlikely to have success if there is not a precise definition of knowledge, skills and attitudes required to become competent at an audiovisual scope.

\section{BACKGROUNDS AND CURRENT SITUATION OF SCIENTIFIC KNOWLEDGE}

According to the Grunwald Declaration (1982) by the UNESCO issued more than 25 years ago, "political and educational systems should recognize its obligation to promote critical comprehension of communication phenomenon among citizens". This document urged to "readjust educational priorities, encouraging the creation of more critical awareness amongst the audience". Nowadays, despite of the widespread influence of media and technologies, this «readjustment of educational priorities» is till necessary and should be, according to the European Union on its last Recommendations by the Commission 20-08-2009 on "Media literacy in the digital 
environment", the main focus of every educational reform. The necessity to modify the educational system is generally identified after social changes or priorities. In this sense, educational priorities should be also modified.

Although certain support is received by international institutions, Education on Audiovisual Communication remains an unexplored issue in educational systems in most areas of the world, except for countries such as Australia or Canada. The lack of a precise and agreed definition on what does being competent in this field mean is especially remarkable. Consequently, there are not specific action plans to enable citizenship to develop appropriate communicative interactions with media at schools and at social or media contexts in general. Particularly in Spain, there are valuable experiences of education on audiovisual communication and there are many research groups which have been carrying out works on this field for two decades. However, after analyzing the actual relevance of these works, we can confirm these experiences are not significant and representatives in society. Specifically, concerning skills conceptualization, there are not many explicit or implicit attempts to define competences or skills on audiovisual competence.

On the other hand, globalization is significantly affecting this phenomenon. International institutions such as the European Commission, the Council of Europe or the UN (Alliance of Civilizations) are increasingly supporting the urgency for global, consistent and sustainable development in media education. Many of these institutions have already designed consensual action instruments. Many examples of these bold initiatives are the following: The "kit for Media Education" or the "Curriculum for training trainers on communicative literacy and the media" by the UNESCO; the European Chart on Media Literacy; and the support received by the Alliance of Civilizations for Media Education, through the organization of conferences and publications. All these initiatives are focused towards an international framework of "knowledge societies". Here there are some examples: The Grunwald Declaration (1982), the Proclamation on Informational Literacy in Alexandria and Lifelong learning (2005), the Paris Agenda for Media Education (2007), the Middle East Conference on Media Education in Saudi Arabia (2007), the International Forum on Media Research (London; Hong Kong, 2008), the Media in Conference held in Nigeria (2008), together with the Recommendations by the European Parliament in 2007 and the C Recommendation (2009) 6464 by the European Commission stating that all member states should provide national data related to educational levels of media education of their citizens (Aguaded, 2012). All these initiatives have been decisive opportunities to define the future, the strategies and the research that should be carried out, shared, experienced and adopted in order to achieve a real social change.

\subsection{Concept of skill}

The concept of skill was initially related to the business world, but it gradually became part of the academic world and it is nowadays a conceptual axis in education reforms in most European countries, as it is in Spain. It would be appropriate now to include the concept of skill into informal education dimensions, including leisure and free time. According to the Recommendations by the European Council last December, 2006 , the concept of "skill" is defined as a set of necessary knowledge, abilities and attitudes in a particular context. It is also possible to define "key skill" or "basic skill" as a multifunctional and transferable set of knowledge, abilities and attitudes needed by everyone in compulsory education process for personal development of individuals, for their inclusion in society and for their access to employment. Given the fact that these characteristics should be able to be transferable, it would be also necessary to aim its implementation in certain contexts and situations, including informal environments and leisure contexts.

The idea of "communication skills" is also immersed in the digital and media environment, in leisure and free time dimensions. This leads us to state that the set of knowledge, skills and attitudes is useful to reach the goals concerning audiovisual skills and this set of abilities should be learnt and implemented with digital tools. In this sense, people developing these competences would have the capacity to get involved in different dimensions, amongst them, the communicative and technological dimension. "The increasing world consensus on media education implies a transformation on the isolated practices in the classroom: they should be implemented at a national curriculum level. In a few words, this theory could be summarized in six key competences in media education: comprehension, critical capacity, creativity, consumption, citizenship and intercultural communication" (Frau-Miegs \& Torrent, 2009).

The Canadian Association for Media Literacy (AML) also introduced some new ideas, and amongst them, it is interesting to highlight the following: presenting the media as constructions, the idea that people interpret messages differently; the transmission of ideological messages, the existence of different languages, styles, techniques, codes, conventions and its esthetical aspects, its commercial, social and political implications, and the close relation between form and content. Our main objective would be to discover if these capacities can be developed in citizens, especially in leisure related contexts involving children, youth, housewives, neighbours, professionals, university students, workers.

\subsection{Current situation regarding scientific knowledge}

Since the emergence of the media in the 50's by the time the concept of "Total Language" was suggested by Vallet, progress has been made in the attempt to define and develop skills in audiovisual communication, by means of projects consisting of reading images, many of them inspired on the work carried out by Freire and Kaplún. Nowadays the problem has become universal, and international agents are investing in updated resources for media education. The Alliance of Civilizations (UN) has developed an on-line information centre focusing on fundamental areas, such as migration, education and, of course, media literacy. This initiative provides on-line resources for media literacy with the aim of providing available didactic material for everybody. For UNESCO there is a clear intention to be spread in many fields: empowering people by means of media literacy to foster equal access to information and to add value to the knowledge-based society. In this way people would be able to interpret and make value judgments on media contents, as well as to develop skills to become creators and producers of these media.

Outstanding researchers attending the Second European Congress of "Media Literacy in Europe: controversies, challenges and perspectives" (Italy, 2009), such as Buckingham, 
Tisseron, Bazalgette, Carlsson, Bevort, Verniers or Piette, agreed on the need of basic media competences available for citizens. According to Buckingham (2007), former professor at the Institute of Education, University of London, these skills should be the following: "developing skills for using technologies, protecting children against harmful content, developing awareness concerning the risks of Internet, promoting access to technology to former excluded groups, fighting against commercial practices, fostering active participation of citizenship and an active role in civil society; promoting free creativity and artistic expression by means of new media and favouring people's communication with the audience".

Over the recent years in Spain, many similar approaches are arising. Under the umbrella of Catalonia's Audiovisual Council and under the coordination of Joan Ferrés, in the year 2005, a group of Spanish and Latin American experts drafted a document with the title "Skills in audiovisual communication" as a first systematic approach to the concept of "communicative skill", described as the "capacity of an individual to interpret and analyze critically images and audiovisual messages, and the capacity to correctly express himself in an communicative environment. This skill is directly related to the knowledge of the media and the basic use of multimedia technologies needed to produce it". In 2006 this proposals were submitted to the Regional Education Ministry and to the Ministry of Education itself by means of CNICE (National Centre of Information and Educational Communication) with designed guidelines concerning actions on the fields of Languages and Literature, Visual and Plastic Arts and Education for Citizenship.

There exists an international awareness of the fact that actions and research must be developed if we want to be successful implementing sustainable education-communication practices involving the majority of citizens, especially in leisure contexts. The European Commission (EU) addressed to the member states its latest recommendations "On media literacy in the digital environment for a more competitive audiovisual and content industry and an inclusive knowledge society", urging them to insist on assessment criteria of the different levels of media literacy in Europe, such as: "fostering systematic research through projects dealing with different aspects and dimensions of media literacy in the digital environment, monitoring the advance of its levels". In this sense, media literacy is related to the capacity to access media education, to critically understand and assess many aspects of the media and its contents, as well as establishing new ways of communication in different contexts. Nevertheless, citizenship is not currently developing its capacities and nobody is pointing a finger at the necessity to create special contents for free time.

\subsection{Our experience}

Our research group has been working since the year 2000 on the use of communication technologies in education through different projects and research, emphasizing the development of media education on the field of non-university education. In this sense, many European research projects have been carried out focusing on education and free time. These projects have been conducted in collaboration with many research centres of Italy, Belgium, France or Portugal. One example of these works is "Valori Comuni", a project designed to analyze intercultural and playful dimension of comic strips in four languages: Italian, French, Spanish, and English. The project called "Glocal Youth.
Text and media context of young people from the north and the south", coordinated by Italy, involved four countries in the research of digital contents of publications for young people along four continents (Asia, Europe, America and Africa). Moreover, over the recent years, we have been developing another project concerning "Implementation of free software in ICT Centres in Andalusia: analysis of the impact of this implementation on the process of teaching and learning", carried out in centres of the eight Andalusian regions, as well as "Elearning platforms for virtualization of subjects".

In 2005, research from the Catalonia's Audiovisual Council (CAC) requested our cooperation with the aim to draft a consensual report at a national level to define the concept audiovisual skill. The result of this work was published in two specialized journals "Comunicar 32" and "Quaderns del CAC". A basic document containing the definition of «competent user of audiovisual communication» was drafted, and the indicators for assessment were also included. As a result of the previous work, this document would be useful in the future to elaborate objectives, processes and contents in audiovisual communication.

In 2007 a second phase started, and the work was supported by the Catalonia's Audiovisual Council and other institutions all along the country, with the main aim to define the scope of an education ready to train for the acquisition of this competence (language, technology, production and programming processes, ideology and values, reception, the audience, and the esthetic dimension), as well as to determine the necessary indicators to assess the competence. The objective of this second research process was to evaluate the level of skill in audiovisual communication of citizens in general, with the aim to certify or implement, if necessary, the education on audiovisual communication, which had been set for the first time in compulsory education. Moreover, this research was also targeting at identifying the most urgent dimensions to insist in. This research was expected to foster the development of an audiovisual literacy policy and to define the objectives, contents, and procedures to be developed on this field. At the moment, the research group already works in 15 out of the 17 Autonomous Regions of Spain. In this phase, a questionnaire on audiovisual communication of citizenship will be taken in order to discover the level of global skill on audiovisual communication and the level of competence in each dimension detailed in that document.

We can affirm there are no previous experiences of assessment of competence level in audiovisual skill. This leads us to the conclusion that this work is a pioneering research setting the grounds for the development of audiovisual contents in audiovisual skill in leisure society.

\section{OBJECTIVES}

The aim of this proposal is to promote a deep and systematic analysis of a barely studied reality; to determine the level of audiovisual skill of citizens when they interact with the media and digital technologies; and to establish digital and audiovisual contents in leisure society. The main reasons to justify this research are the following:

(1) Relevance. Media consumption needs the development of audiovisual skills in citizenship to avoid manipulations and audiovisual illiteracy. 
(2) Innovation. There is not current research in Spain carried out in real contexts.

(3) International demand. European and International institutions (UNESCO, UN, European Parliament and European Commission) are increasingly claiming for the implementation of media literacy programmes and specific assessment systems for them.

(4) Need of quality audiovisual and digital contents to foster media literacy in the digital and leisure society.

The initial hypothesis establishes that media consumption as well as digital content consumption at home, in social environments or in other contexts do not guarantee the appropriate comprehension of contents. It is only possible to create systematic and global action plans to foster intelligent interactions of citizens with the media after analyzing the different levels of audiovisual skill of the different social sectors. For this purpose, it would be necessary to analyze and suggest quality contents for digital leisure. Among these contents, for example, those promoting media literacy should be taken into account.

Daily media consumption does not guarantee audiovisual skill, but it is necessary to achieve a critical training in audiovisual and media literacy: minimum skills and attitudes (not professional skills), required to wisely interpret the wave of images, media and telematic visual, audio, audiovisual contents which are a essential part of our day-to-day life. Creating audiovisual contents for the digital society is becoming a social urgency which should become the focus of future research.

\subsection{Specific objectives}

- To detect the main needs and shortages of the chosen sample of Andalusian population in terms of skill levels in communication: technology, critical reading, and audiovisual production.

- To re-define reference indicators to determine the grades of skills in different sectors of population in the different regions in Andalusia.

- To analyze the levels and grades of audiovisual skill of selected samples.

- To investigate experiences of "good practices" in audiovisual literacy and contents of digital leisure.

- To design digital and audiovisual training proposals in the field of media education for audiovisual communication in leisure society: language, technology, ideology and values, production and programming, reception, audiences and the esthetic dimension.

\section{METHODOLOGY AND WORK PLAN}

There exist many appropriate ways of collecting information in order to investigate in depth a social phenomenon such educational facts are (Corbetta, 2003): analysis, observation, and questions. We will use these tree resources in the initial step of our research, before the use of proposals for training on digital contents in the framework of leisure society.

The survey will be used as basic methodology, as our main aim is to depict the current state of skill levels in audiovisual communication. The survey, as a research method, can be useful to obtain solutions to questions, in descriptive terms and concerning variable relations. Its main purpose would be to describe the conditions of a reality, to identify norms and patterns, and to determine relations among events (Buendía, 1997). In this sense, we are going to: 1) identify and describe needs and shortages of Andalusian population in relation with levels of communication skills: technology, critical reading, and audiovisual production; 2) to redefine reference indicators to determine the grades of competence in communication among different sectors of population of all the regions of Andalusia; 3 ) to analyze the levels and grades of audiovisual skill of selected samples; 4) to investigate on experiences of "good practices" in audiovisual literacy and contents of digital leisure.

Its usage as basic methodology is justified because of the need to generalize the results obtained in a wide sample and also because of its proven efficiency as a research tool to collect opinions, ideas, and attitudes of the educational community.

Despite of the fact that self-completion questionnaires (Cohen \& Manion, 1990) will be the usual instrument, our work would be complemented by individual interviews (Rincón et al., 1995). Questionnaires would provide data for the quantitative analysis. On the other hand, interviews would provide qualitative and fine-tuned information, in order to contrast and confirm the information. The in-depth interviews would be used to assess attitudes and abilities of citizens.

Focus group technique would be also developed to collect social significance and to understand the media consumption phenomenon, as well as to detect the main underlying concerns.

\subsection{Population and sample}

This research covers a group of people from Andalusia. The selected sample includes groups of different variables according to age: children (0-12); teenagers (12-18); young people (18-26); adults (27-64) and the elderly $(+64)$. The variables included also refer to cultural level (university studies), place of residence ( \pm 30000 inhabitants), regions of Andalusia (the eight Andalusian regions), gender, occupation, kind of social association in free time (associations, groups, collectives...)

Sample selection would be carried out according to previous protocols initially defining random samples for the first rounds of competence and later purposive samples with best practices parameters for the interviews and the groups of discussion. This research does not aim exclusively to represent the real situation in Andalusia. Its main target is to depict the complex reality we face, to focus on the urgency to develop new training strategies adapted to shortages and real needs in media interactions, audiovisual skill levels, and its social responsibilities.

Consequently, in a first sample, 600 Andalusian citizens according to the above-described variables would be selected for the application of the version 1.0 of the questionnaire on audiovisual skill, to be complemented later with a second sample of 1,200 individuals to whom the version 2.0 of the questionnaire would be applied in an improved digital format. Afterwards, 16 focus groups with 80 participants in total coming from all the regions of Andalusia would be selected as purposive samples according to best practices protocols, with the aim to systematize shortages and to structure suggestions for training plan with multimedia and digital contents.

There would be also 8 in-depth interviews with informers and 8 eyewitness observations in best practices centres on the development of digital and multimedia contents for audiovisual skill in free time and leisure environments.

\subsection{Work plan}

The first phase of our Project would consist on the analysis of the national and international outlook regarding researches on leisure societies and audiovisual skill, as well as the analysis of precedent studies linked to the six dimensions of audiovisual 
skill. The second phase would consist of the detection of needs and shortages of Andalusian citizenship concerning the development of audiovisual skill by means of the application of a questionnaire to assess the grade of audiovisual skill prepared by the national research group. This questionnaire would be applied to 600 Andalusian citizens, to random samples selected according to different variables, such as the geographical situation, educational level, age, cultural level... The information collected would be processed by means of statistical analysis, qualitative and quantitative data. Finally, the partial results on the grade of audiovisual skill would be systematized. The third phase would permit the redefinition and application of new reference indicators to determine the grade of communication competence in sectors of population of all the Andalusian regions. The fourth phase would consist of analyzing the training initiatives taken by regional institutions and civil society in the field of media education in audiovisual communication in leisure society for the citizenship in Andalusia. Finally, the work would include the conclusions and future perspectives of the study.

\subsection{Expected achievements}

The main targets of this work, in relation with the initiatives of our research, would be the following:

- To boost media literacy and Internet as the best way to know and critically assess contents, messages and different formats of the media, fostering the development of strategies and audiovisual skills.

- To achieve wide-ranging effect of media education in society, with a practical and multidisciplinary dimension, covering all different areas: politics, literature, society, art...

- To foster media production among students so that they can become active users instead of mere observers.

In this sense, our contribution and the results obtained would be useful for:

(1) The design and assessment of @1famed: Observatorio Digital de Contenidos Multimedia para Alfabetización Digital, with the company of technological transference called Diteh.

(2) The design and assessment of "Mira", six digital television programmes to analyze language, technology, ideas values, production and programming, receptors and audiences and the esthetic dimension of audiovisual image, with the support of the company Canal Luz TV.

(3) The design and assessment of "Imago", a media literacy course in digital society online, with the support of the company ITEM Formación.

Generally, the outcomes of this research support the idea of urgency for systematic criteria to determine the need of audiovisual skill in citizens, as well as to improve the reachinglearning processes, frequently influenced by the levels of audiovisual literacy. The results could be easily found in other regions, at a European or international scope, as we are witnessing a globalization process at the service of society as a whole. This project is supported by the Media Education Program of the Alliance of Civilizations (UN). After this programme and together with the Spanish Ministry of Education it has been recently agreed to set up in Spain the UN
International Institute of the Alliance of Civilizations (ONU_IIAC).

\section{REFERENCES}

Aguaded, J.I. (2012). United Nations aiming at Media Literacy Education. Comunicar, 38, 7-8. DOI: http://dx.doi.org/10.3916/C382012-01-01.

Buendía, L. (1997). La investigación por encuesta. In L. Buendía, P. Colás, \& F. Hernández (Eds.), Métodos de investigación en Psicopedagogía. Madrid: McGraw-Hill.

Buckingham, D. (2007). Beyond Technology: Children's Learning in the Age of Digital Media. Cambridge: Polity Press.

Cohen, L. \& Manion, L. (1990). Investigación educativa. Madrid: La Muralla.

Commission of the European Communities (2009). Commission recommendation 20.8.2009 on media literacy in the digital environment for a more competitive audiovisual and content industry and an inclusive knowledge society. Bruxelles. Retrieved from http://ec.europa.eu/culture/media/literacy/docs/recom/c_2009_6464_en.pdf.

Corbetta, P. (2003). Metodología y técnicas de investigación social. Madrid: McGraw-Hill.

Del Rincón et al. (1995). Técnicas de investigación de ciencias sociales. Madrid: Dykinson.

European Union (2006). Recommendation of the European Parliament and of the Council of 18 December 2006 on key competences for lifelong learning. Brussels: European Union. Retrieved from http://eurlex.europa.eu/LexUriServ/LexUriServ.do?uri=OJ:L:2006:394:001 0:0018:en:PDF

Frau-Meigs, D. \& Torrent, J. (Eds.) (2009). Mapping Media Education Policies in the World. Visions, Programmes and Challenges. New York: The United Nations-Alliance of Civilizations in co-operation with Grupo Comunicar. Retrieved from http://www.unaoc.org/images//mapping_media_education_book_final_version.pdf.

Nielsen (2009). How Teens Use Media. A Nielsen report on the myths and realities of teen media trends. New York: The Nielsen Company. Retrieved from http://blog.nielsen.com/nielsenwire/reports/nielsen_howteensusemedia june09.pdf.

Parlamento Europeo (2008). Informe sobre la alfabetización de los medios de comunicación en un mundo digital. Documento de sesión. Retrieved from www.europarl.europa.eu/sides/getDoc.do?pubRef=//EP//TEXT+REPORT+A6-2008-0461+0+DOC+XML+V0//ES

Prensky, M. (2001, October). Digital Natives, Digital Immigrants, In On The Horizon, MCB University Press, 9(5). Retrieved from www.marcprensky.com/writing/Prensky\%20-\%20Digital\%20Natives, $\% 20$ Digital\%20Immigrants\%20-\%20Part1.pdf

UNESCO (1982). Grunwald declaration on media education. UNESCO: Grunwald, Federal Republic of Germany. Retrieved from http://www.unesco.org/education/pdf/MEDIA_E.PDF

\section{ACKNOWLEDGMENT}

Estudio financiado en la Convocatoria $\mathrm{I}+\mathrm{D}$ del Ministerio de Ciencia e Innovación con clave: EDU2010-21395-C03-03 y en el Proyecto de Excelencia de la Junta de Andalucía SEJ-5823. 